First publ. in: Aquatic Botany 78 (2004), pp. 307-318

\title{
Spatio-temporal dynamics and plasticity of clonal architecture in Potamogeton perfoliatus
}

\author{
Susanne R. Wolfer*, Dietmar Straile \\ Limnological Institute, University of Konstanz, D-78457 Konstanz, Germany
}

Received 19 March 2003; received in revised form 26 August 2003; accepted 16 November 2003

\begin{abstract}
Above- and below-ground clonal growth architecture was compared for two neighbouring patches of Potamogeton perfoliatus L. in Lake Constance, representing typical sparse and dense growth types. A detailed map of individual ramets and their corresponding rhizome network was produced and the seasonal development of ramet sprouting and rhizome growth was reconstructed. Rhizomes extended at rates ranging between 40 and $63 \mathrm{~cm}$ per year, and added a new shoot for every $1-20 \mathrm{~cm}$ of rhizome produced. The main rhizome axis grew in a semi-linear fashion, with deviation means of 15 and $24^{\circ}$, and developed $0-0.5$ branches per plant, with an insertion angle from $15-90^{\circ}$. Total rhizome length of all plants amounted to 5 and $11 \mathrm{~m} \mathrm{~m}^{-2}$ at the two sites. The total biomass produced at the two sites differed by 10 -fold. The neighboring patches also showed different allocation patterns which are interpreted as foraging.

Contrary to the prediction of the foraging hypothesis, there was only a small difference in mean spacer length between sites. On the other hand, the spacer length was plastic relatively to total biomass. We propose that spacer length is not an independent part of the foraging strategy, but rather a result of overall productivity and biomass allocation. Phosphorus content of plant tissue at the more productive site was two-fold higher than that at the less productive site which suggests that the different growth types may be due to differences in sediment nutrient availability: in situ fertilization of a less productive site increased the $\mathrm{P}$ content to those levels of the productive site. In situ fertilization also resulted in higher ramification, lower root allocation and decreased spacer length and confirmed the foraging capability of $P$. perfoliatus.

(c) 2004 Elsevier B.V. All rights reserved.
\end{abstract}

Keywords: Macrophyte; Clonal architecture; Rhizome; Biomass allocation; Foraging; Spatial growth

\footnotetext{
* Corresponding author. Tel.: +49-7531-883364; fax: +49-7531-883533.
}

E-mail address: susanne.wolfer@uni-konstanz.de (S.R. Wolfer). 


\section{Introduction}

Macrophytes usually occur in patches which play a vital role in structuring of the littoral zone of lakes (Jeppesen et al., 1997). Potamogeton perfoliatus L. forms such spatial patterns ranging from semi-continuous to widely dispersed patches over a wide range of scales (Walser, 1996; Lehmann, 1997). In many lakes, Potamogeton patches change location, size, shape and density in the long run (Schmieder, 1997) but remain spatially stable in the medium range (Walser, 1996; Gafny and Gasith, 1991), whereas in other lakes, they disappear and reappear from year to year (Scheffer et al., 1992). The presence or absence of macrophytes, as well as size, shape and density of vegetation patches influence element cycles (Barko and James, 1997) and littoral food webs (Lauridsen et al., 1996). Despite the recognition of the importance of spatial patterns for the littoral ecosystem, it is not yet understood how these patterns are generated (Lehmann, 1997) and which role can be attributed to: (a) architectural growth rules; (b) morphological plasticity in response to spatially heterogeneous environmental factors; and (c) competition between species or genets.

The concept of plant architecture suggests that each plant species has its own growth form (Bell, 1984). Compared to non-clonal plants, clonal plant architecture comprises additional growth rules such as number of ramets, branching patterns (frequency and angle) of the rhizome, and the rhizome spacer length in between consecutive shoots (Callaghan et al., 1990; Huber et al., 1999). These rules are plastic to a certain degree allowing for adaptive responses to a spatially heterogeneous environment (Marbà and Duarte, 1998).

Since seeds are considered as relatively unimportant for propagation of Potamogeton (Walser, 1996), the knowledge of its architectural programme is essential for understanding the different rates and patterns at which this plant occupies space. Information on clonal growth rules is also important for the understanding and management of recolonization and restoration of littoral biotopes. Whereas descriptive mappings of aquatic vegetation patches have a long tradition, the importance of modular structure in studies of macrophyte stands has only recently been acknowledged. Most previous work on aquatic plant architecture has been published for seagrasses (e.g. Marbà and Duarte, 1998; Molenaar et al., 2000) and emergent macrophytes (e.g. Clevering and Hundscheid, 1998; Klimes, 2000), whereas the clonal morphology of submersed freshwater macrophytes has received less attention (but see Idestam-Almquist and Kautsky, 1995). In general, architectural studies lack spatial information, and vice versa, furthermore investigations on temporal aspects of clonal architecture and spatial pattern formation are rare. In all above-mentioned fields, comprehensive studies on $P$. perfoliatus are missing.

Below, we present detailed information on the: (a) characteristics of clonal growth architecture (length of rhizome spacers, branching intensity, branching angle) of $P$. perfoliatus; (b) temporal dynamics; and (c) natural variability of two typical growth types in Lake Constance. One site was characterized by lush patch growth with shoots reaching the water surface (referred to as 'rich growth' below), whereas at the other site, the shoots remained low and sparse (referred to as 'poor growth' below). The conclusions of the study are supported by an in situ fertilization experiment and will be discussed in the light of foraging theory. 


\section{Materials and methods}

\subsection{Study site and general definitions}

The growth architecture of $P$. perfoliatus was investigated at the 'Lower Basin' ('Untersee') of Lake Constance $\left(9^{\circ} 18^{\prime} \mathrm{E}, 47^{\circ} 39^{\prime} \mathrm{N}\right)$, a large, subalpine lake on the borders of Germany, Switzerland, and Austria. The sub-basin has a surface area of $62 \mathrm{~km}^{2}$, a mean depth of $13 \mathrm{~m}$ and a maximum depth of $40 \mathrm{~m}$ (Wessels, 1998) and holds an extensive littoral area. $P$. perfoliatus is the second most common submersed macrophyte species in the area (Schmieder, 1997), has a local vegetation period from approximately May to September and survives the winter in the form of subterraneous turions. The patches with Sampling Sites A and B $\left(1 \mathrm{~m}^{2}\right.$ each) were located in a bay south of the north-western edge of the island of Reichenau, at a depth of approximately $2.2 \mathrm{~m} \pm$ $0.2 \mathrm{~m}$ throughout the growth period. The distance between the two mono-specific stands was $30 \mathrm{~m}$.

For description of patch characteristics, the following terminology will be used: 'Plant' is defined as a complete unit of ramets connected by rhizomes, originating from a single primary shoot. 'Ramet' is a single module of a clonal plant, consisting of shoot, rhizome and roots. Spacer length is the rhizome length between two consecutive shoots of the same plant (Fig. 1).

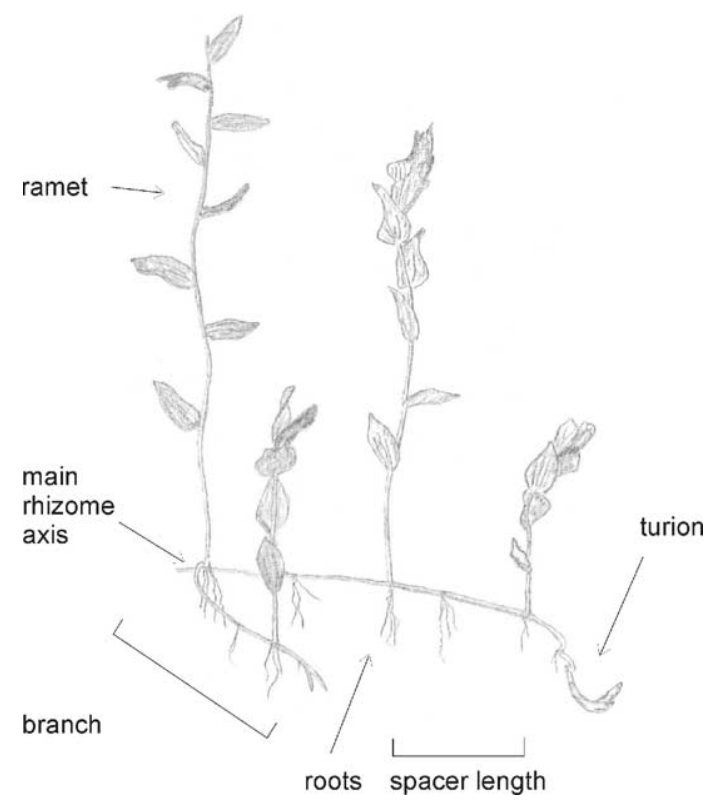

Fig. 1. Apical section of $P$. perfoliatus plant. Rhizome diameter increases in growth direction. Turions are formed at main axis and side branches. The last ramets are more stout than the older ramets. 


\subsection{In situ growth monitoring}

On 01 May 2000, when the first primary shoots were visible, two square frames with $1 \mathrm{~m}$ side length and a $10 \mathrm{~cm} \times 10 \mathrm{~cm}$ grid subdivision were placed on the lake sediment at Site $\mathrm{A}$ and $\mathrm{B}$. The position of individual shoot bases within the grid and their corresponding lengths were noted on PVC-boards by snorkelers on four occasions in May, June and August 2000. The quadrats represent open systems: plants that had their origin outside could grow into the quadrats and plants from inside were allowed to grow out of the quadrats.

\subsection{Architectural analysis}

Final harvest was made by SCUBA divers in August, 2000. Each shoot was labelled at the top as well as close to the sediment. A transparent board $\left(1 \mathrm{~m}^{2}\right)$ placed above the sampling quadrat was used to draw a map of shoot positions. The shoots were cut-off directly above the sediment and harvested with the upper set of tags before the sediment was carefully removed by hand up to a depth of $15 \mathrm{~cm}$. Rhizome networks were removed as completely as possible with the lower set of tags attached.

In the lab, shoot length, ramifications and number of ramets per plant were recorded. All plants were cleaned and separated into shoots, rhizomes and roots. Turions were discarded because owing to their deep position in the sediment, they could not be harvested quantitatively. Plant fractions were dried at $105^{\circ} \mathrm{C}$ until constant weight was achieved. After allowing for cooling down to room temperature, dry weights were determined on an analytic scale. Ramet number, branching frequency, branch angle, ramet length, a subset of spacer lengths, total rhizome length, specific rhizome weight, and biomass allocation values were determined for all plant material included in square-meters. For calculations of plant size, plant rhizome length, and radial angle, only those plants growing completely within the quadrat were considered. Spacer length was calculated as Euclidian distance between the nearest sibling ramets. Calculated spacer lengths compared adequately with a subset of measured spacer lengths $(r=0.98, P<0.001)$.

The drawings of shoot positions and rhizome networks were scaled down by transformed coordinate systems. The mapping of shoots over the investigation period and the additional information about connections between these shoots made it possible to assign daughter shoots to parent shoots and to reconstruct the spatio-temporal growth of individual rhizome systems. A rough estimate of the temporal dynamics of biomass allocation was based on the number of shoots, mean shoot length and the assumption of constant weight-specific allocation into shoots and ramets. Angles were determined to the nearest degree on the reconstructed map.

\subsection{Fertilization experiment and tissue analysis}

On 2 July 2001, five typical poor growth areas of $0.25 \mathrm{~m}^{2}$ were fertilized ('fertilized type A') with $250 \mathrm{~g}$ slow-release N-P-K-fertilizer 'Plantacote Depot $4 \mathrm{M}^{\circledR}$ (14\% N, 9\% $\mathrm{P}_{2} \mathrm{O}_{5}, 15 \% \mathrm{~K}_{2} \mathrm{O}$ ), additional three low growth sites were assessed as control ('Type $\mathrm{A}$ '). All sites had an initial density of eight shoots $\mathrm{m}^{-2}$ and were located in the same lake area as $\mathrm{A}$ and B, at a maximum distance of $50 \mathrm{~m}$ between each other. On 15 August 2001, 
the complete plants including rhizomes were removed from the sediment and processed in the same way as those from locations A and B. Leaf tissue of the fertilized and poor growth sites as well as additional rich growth sites ('Type B') was analyzed for carbon and nutrient content. C was determined by Autoanalyzer (ThermoQuest NCS-2500) after combustion. P and $\mathrm{N}$ values were determined by AutoanalyzerII (Bran \& Luebbe) following digestion with potassium persulfate. For the statistical analysis of percentages, data were arcsin transformed. Statistical analyses were performed with SAS software (SAS Institute Inc., Cary, NC, USA, 1999-2001).

\section{Results}

\subsection{General growth characteristics}

At the first field visit, ramet numbers were identical, but during the following 2 months, ramet numbers were always higher at Site B than at Site A. The sites also showed a strikingly different development in several other aspects (Fig. 2). At Site A, biomass at harvest was more than 10 -fold lower $\left(17 \mathrm{~g} \mathrm{DW} \mathrm{m}^{-2}\right)$ than at Site B $\left(200 \mathrm{~g} \mathrm{DW} \mathrm{m}^{-2}\right)$. The maximum density was 90 ramets $\mathrm{m}^{-2}$ at Site A compared to $210 \mathrm{~m}^{-2}$ at Site B (Fig. 3a). The calculated number of plants was 18 with $5 \pm 1$ ramets each at Site A, compared to 25 plants with $8 \pm 3$ ramets each at Site B. On average, shoots measured $12 \mathrm{~cm} \pm 7 \mathrm{~cm}$ at Site A compared to $66 \mathrm{~cm} \pm 75 \mathrm{~cm}$ at Site B (Fig. 3b). At Site B, many shoots had reached the water surface and formed a canopy (285 cm maximum shoot length), whereas at Site A the longest shoot measured only $48 \mathrm{~cm}$.

\subsection{Growth architecture}

Primary P. perfoliatus ramets developed plagiotropic stems (lateral rhizomes) initiated at the ramet base, which produced further ramets on every second rhizome node and adventitious roots at every node (Fig. 1). Overwintering organs, also called turions, were formed at the end of the main rhizome as well as on most branch tips. Rhizome branching was acropetal and occurred only at the base of ramets. The maximum level of branching encountered at the research site was first order. A special case were primary ramets bearing two rhizome axes at two different vertical nodes. Rhizome branch growth was subordinate to the growth of the main rhizome axis. No true branches were found at Site A, whereas at Site B every second plant (every 17 th ramet) had developed a branch. Initial rhizomateous growth direction appeared to be random. The mean radial angle was $15^{\circ} \pm 12^{\circ}$ at Site A and $24^{\circ} \pm 25^{\circ}$ at Site B, and the mean insertion angle (branch angle) was $68^{\circ} \pm 15^{\circ}$ at Site B $\left(15-90^{\circ}\right)$. Especially at Site B, rhizomes of different plants crossed each other frequently.

The spacer length was highly variable at both sites ranging from 1 to $20 \mathrm{~cm}$ of rhizome produced between two shoots (Fig. 4a). However, average spacer lengths were similar with $8.0 \pm 3.2 \mathrm{~cm}$ at Site A and $7.6 \pm 3.4 \mathrm{~cm}$ at Site B. Part of the spacer length variation can be attributed to the order of shoots (Fig. 4b). At Site B, spacing increased in the direction of new ramet recruitment. Average distance between ramet 6 and $7(11 \mathrm{~cm})$ was almost three times the distance between primary and secondary ramets. In contrary, spacer length at Site 
Site A

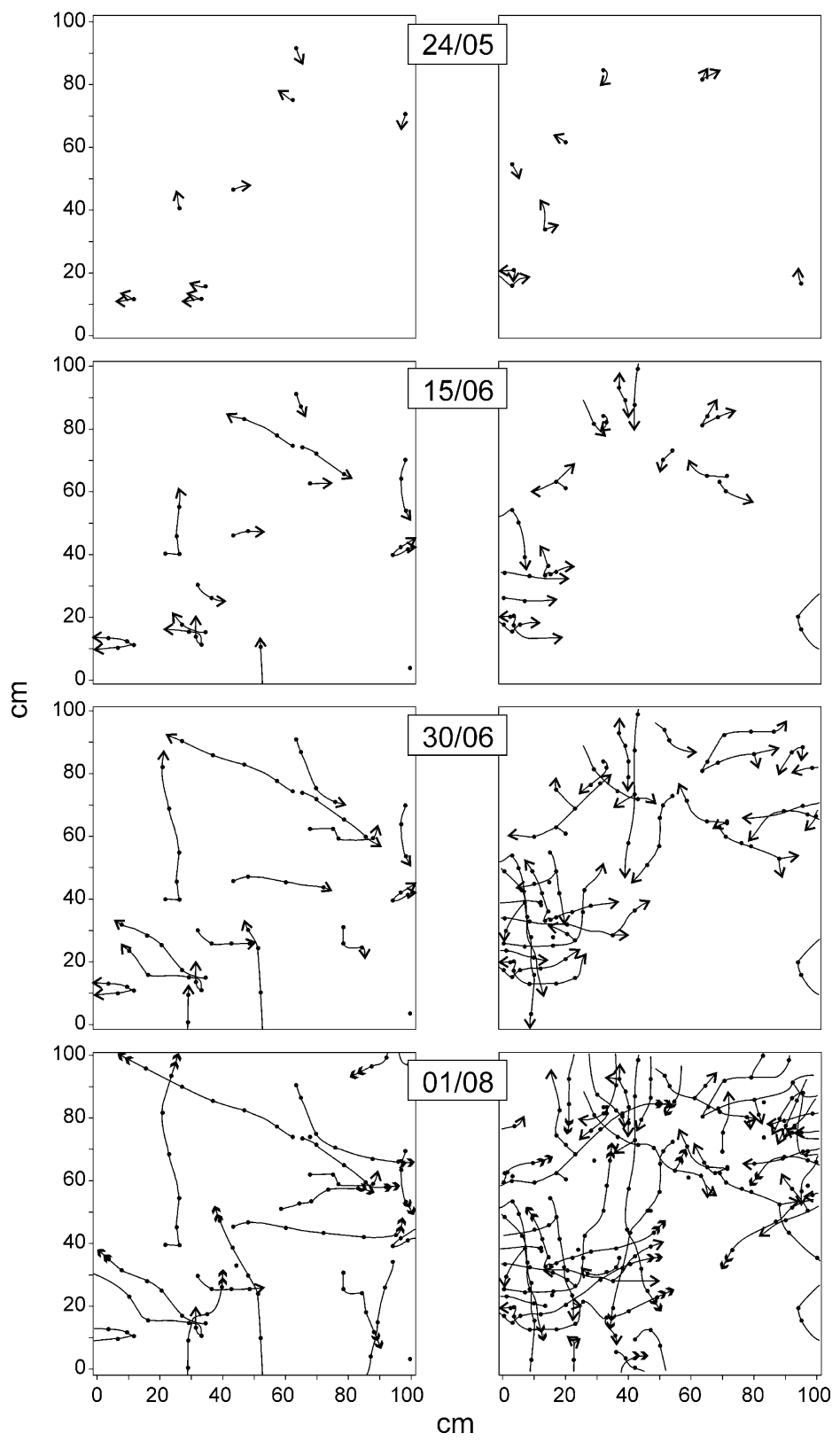

Fig. 2. Reconstructed spatio-temporal growth dynamics of $P$. perfoliatus at (A) poor growth and (B) rich growth site between May 24 and August 01. Points represent ramets, lines show rhizome connections, arrows indicate growth direction, double arrows show sites of turion formation. 

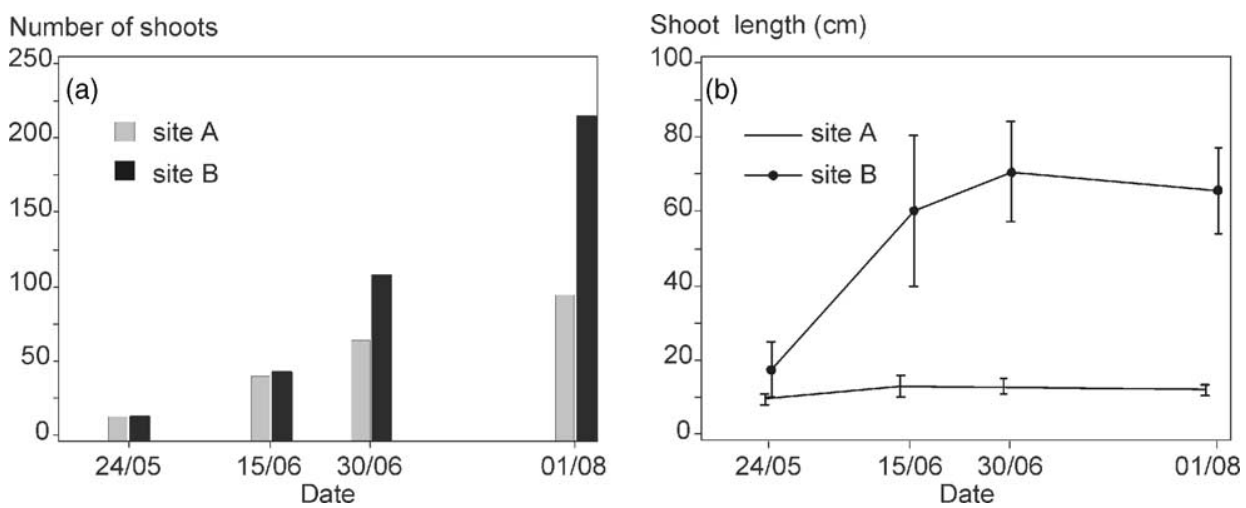

Fig. 3. (a) Temporal development of ramet numbers, and (b) average shoot length \pm S.E. of P. perfoliatus at (A) poor growth and $(\mathrm{B})$ rich growth site.

A approached a constant already between the secondary and tertiary ramets. Spacer order (ANOVA: $\left.F_{1,162}=48.5, P<0.0001\right)$ and the square of spacer order $\left(F_{1,162}=24.1\right.$, $P<0.0003$ ) explained $37 \%$ of the variability of spacer length. The significant contribution of the square root of spacer length indicated a nonlinear relationship between the length and order of spacers. After accounting for the effects of spacer order, analysis of covariance showed that the two sites differed significantly in spacer length $\left(F_{1,160}=12.3, P<0.001\right)$ but also in the increase of spacer length with spacer order $\left(F_{1,160}=10.4, P<0.001\right)$. The site effect, however, increased the adjusted $r^{2}$ of the model by only $4 \%$, showing its secondary importance compared to the effects of spacer order.

Final total rhizome length was $5.4 \mathrm{~m}$ at Site A compared to $11 \mathrm{~m}$ at Site B. The lower weight-length relationship of rhizomes at Site A $\left(6.9 \mathrm{mg} \mathrm{cm}^{-1}\right)$ compared to Site B $\left(7.7 \mathrm{mg} \mathrm{cm}^{-1}\right)$ was probably due to a smaller rhizome diameter at Site A. Mean rhizome
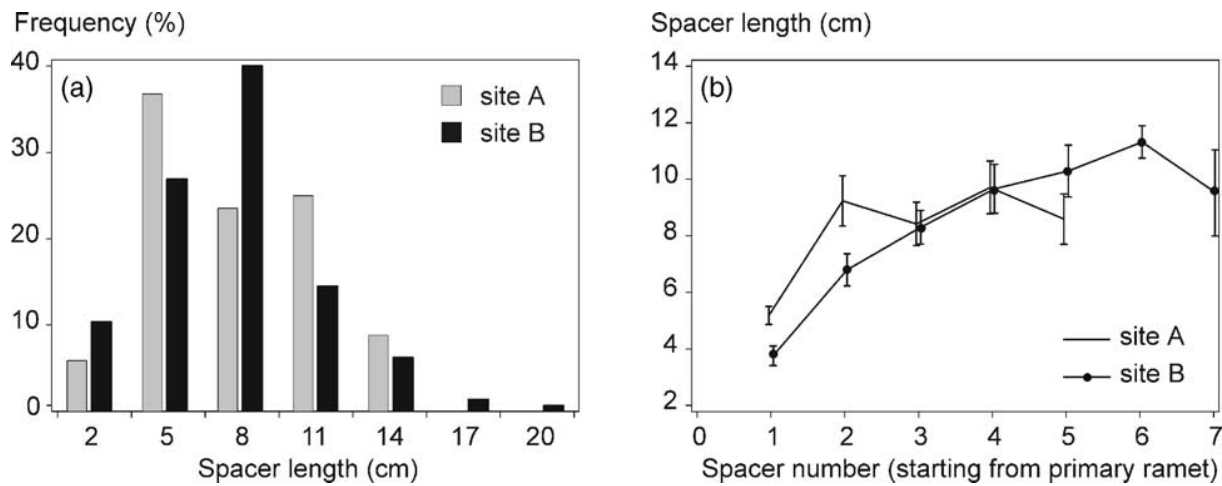

Fig. 4. (a) Frequency distributions of spacer lengths, values on $X$-axis indicate midpoints of intervals; (b) spacer length \pm S.E. between primary and higher order shoots (main axis only) of $P$. perfoliatus at (A) poor growth and (B) rich growth site. 

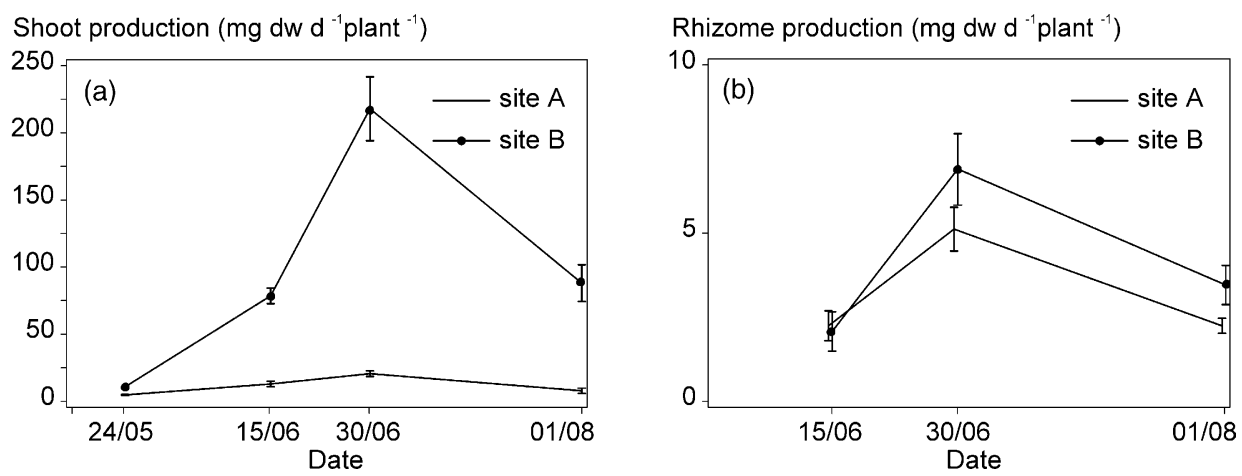

Fig. 5. (a) Shoot growth rate \pm S.E. and (b) rhizome growth rate \pm S.E. per plant of $P$. perfoliatus at (A) poor growth and (B) rich growth site.

growth of individual plants ranged between $40 \mathrm{~cm}$ per year (Site A) and $63 \mathrm{~cm}$ per year (Site B) and determines the maximal extension of the outer perimeter of a patch.

\subsection{Biomass allocation}

At the time of harvesting, Sites A and B differed considerably in biomass allocation. Shoot, rhizome and root biomass amounted to $73 \%, 22 \%$ and $5 \%$ of total dry weight at Site A compared to $95 \%, 4 \%$ and $1 \%$, respectively, at Site B. The estimation of temporal dynamics of biomass allocation (Fig. 5a and b) shows that the initial shoot growth rates were similar. At the second field visit, the shoot growth rate at Site B was several times higher than at Site A (Fig. 5a), which implies a higher total photosynthetic capacity. Despite the large difference in photosynthetic tissue, the rhizome growth rates showed no significant difference between the two sites (Fig. 5b).

\subsection{Fertilization experiment and tissue analysis}

Fertilization of plants resulted in longer shoots, almost three-fold biomass ( $t$-test, $P<$ $0.08)$ and a doubling in shoot number $(t$-test, $P<0.08)$. Mean rhizome length was shorter in the fertilized treatment $(5.1 \mathrm{~cm})$ than in the control $(6.4 \mathrm{~cm})(t$-test, $P<0.06)$. The unfertilized plants had no branches, whereas under fertilization, an average of 3.6 branchings per quadrat was found. Shoot allocation was higher $(t$-test, $P<0.03)$ and rhizome and root allocation were lower $(t$-test, $P>0.05$ and $<0.01$ ) in the fertilized quadrats than in the controls (Table 1).

Table 1

Biomass allocation (\% dry weight) of $P$. perfoliatus in poor growth (Type A, $n=3$ ), and fertilized poor growth (fertilized Type A, $n=5$ ) quadrats

\begin{tabular}{llll}
\hline & Shoot \pm S.D. $(\%)$ & Rhizome \pm S.D. $(\%)$ & Root \pm S.D. $(\%)$ \\
\hline Type A & $64 \pm 4$ & $29 \pm 1$ & $7 \pm 3$ \\
Fertilized Type A & $80 \pm 10$ & $17 \pm 9$ & $3 \pm 1$ \\
\hline
\end{tabular}


Table 2

$\mathrm{N}$ and $\mathrm{P}$ contents (\% dry weight), C:N, C:P and N:P weight ratios of $P$. perfoliatus leaf tissue in poor growth (Type $\mathrm{A}, n=3$ ), fertilized poor growth (fertilized Type $\mathrm{A}, n=5$ ), and rich growth (Type $\mathrm{B}, n=5$ ) quadrats

\begin{tabular}{lllllr}
\hline & $\% \mathrm{~N}$ & $\% \mathrm{P}$ & $\mathrm{C}: \mathrm{N}$ & $\mathrm{C}: \mathrm{P}$ & $\mathrm{N}: \mathrm{P}$ \\
\hline Type A & $1.7 \pm 0.4$ & $0.14 \pm 0.03$ & $22.4 \pm 4.4$ & $268 \pm 55$ & $12.2 \pm 2.5$ \\
Fertilized Type A & $3.1 \pm 0.8$ & $0.36 \pm 0.11$ & $13.8 \pm 3.9$ & $121 \pm 40$ & $8.7 \pm 0.9$ \\
Type B & $2.5 \pm 0.3$ & $0.35 \pm 0.11$ & $16.1 \pm 1.8$ & $121 \pm 29$ & $7.5 \pm 1.6$ \\
\hline
\end{tabular}

$\mathrm{N}$ content (percentage dry weight) was lower in Type A plants than in fertilized Type A plants (Tukey's HSD test, $P<0.005$ ), $\mathrm{P}$ content (percentage dry weight) was lower in Type A plants than in fertilized Type A plants and rich growth Type B plants (Tukey's HSD test, $P<0.001$ ), and $\mathrm{C}: \mathrm{N}, \mathrm{C}: \mathrm{P}$ and N:P weight ratios of leaf tissue were higher in Type A plants than in fertilized Type A plants and rich growth Type B plants (Tukey's HSD test, all $P<0.006$; Table 2).

\section{Discussion}

The results of our study show a common architectural base-programme at two neighboring stands of $P$. perfoliatus, but also striking variability in some growth characteristics including 10-fold total biomass, two-fold density, five-fold shoot length, two-fold total rhizome length, higher branching frequency, and higher biomass allocation to shoots and less to roots at Site B compared to Site A.

The unequal nutrient concentrations of plant tissue at the two sites is a strong indication that growth differences were due to differences in sediment nutrient availability (Langeland et al., 1983; Hilbert, 1990), which is known to show considerable spatial variability (Downing and Rath, 1988). Causes such as water column nutrients, light conditions and currents are unlikely because the two patches are located close by. Genotypic differences are improbable because Potamogeton propagates mainly vegetate in Lake Constance (Walser, 1996). Also the increase in tissue $\mathrm{P}$ in the fertilized quadrats suggests that type A plants were P limited. In fact, the P content of Type A plants $(0.14 \%)$ is close to that considered as limiting for aquatic macrophytes (0.13\%) by Gerloff and Krombholz (1966).

Foraging theory considers changes in branching frequency, spacer length, and biomass allocation as mechanisms for the preferential location of modules in favorable microsites, and as means of an improved exploitation of resources such as light or nutrients (Hutchings, 1997). Intra-specific clonal variability due to nutrient availability has been described for terrestrial plants (Cheplik, 1995) and seagrasses (Pérez et al., 1994). As predicted by foraging theory, we found increased branching intensity at the rich Site B as well as in the fertilized quadrats. Branching intensity is positively related to nutrient supply in many terrestrial clonal plants (Hutchings and De Kroon, 1994), aquatic freshwater plants (Evans, 1988), and seagrasses (Terrados et al., 1997) and is thought to maximize the number of ramets at a suitable site.

As predicted by foraging theory, plants at the nutrient-deficient site allocated considerably more biomass to roots than plants at the rich site, and plants in the controls of the 
fertilization experiment allocated more biomass to roots than the fertilized plants. This allocation rule has been confirmed by a variety of experiments with clonal terrestrial plants (review of Hutchings, 1997) and submersed macrophytes (Kautsky, 1991; Reusch et al., 1994). Recently, it has been proposed that allocation differences under different nutrients budgets are rather a consequence of allometry than of morphological plasticity, as smaller plants frequently show a higher allocation to below-ground structures (Gedroc et al., 1996; Müller et al., 2000). Site A ramets, however, have ceased height growth in favor of producing longer rhizomes and additional modules and, therefore, represent an architectural model different from that of Site B. Hence, the observed differences in biomass allocation are apparently not the result of allometric differences, but rather the result of different growth strategies.

Mean spacer length did not differ strongly between the two sites. According to the foraging hypothesis, however, plants in good habitats (B) should have shorter spacers in order to place a maximum amount of shoots in the favorable habitat while plants in less favorable habitats (A) should grow long spacers in order to escape from the bad site. Although some investigations confirm the hypothesis for rhizomatous species, other researchers found indifferent or even longer rhizomes in more favorable habitats (De Kroon and Hutchings, 1995). To explain the latter results, Hutchings and De Kroon (1994) proposed the growth hypothesis (see also Stoll et al., 1998), according to which spacer length should increase at favorable sites as they allow a higher productivity. The increase in spacer length with the order of ramets at both stands is, for example, in accordance with the prediction of the 'growth hypothesis' and can be interpreted as a result of an increasing overall productivity of a rhizome system with increasing amount of photosynthetically active and clonally integrated ramets. The lack of distinct differences between the mean spacer length at Sites A and $\mathrm{B}$, however, can neither be explained by growth hypothesis nor foraging theory alone. We, therefore, suggest that a synthesis of both theories is necessary for a complete understanding of spacer length in Potamogeton. Despite having only one-tenth of photosynthetically active biomass, plants at the poor site produced the same average spacer length and more than $60 \%$ of the total rhizome length compared to Site A plants. Principally, longer rhizomes at inhospitable sites can be achieved by means of two mechanisms: (a) by an increased biomass allocation into rhizome tissue, as seen in our study; and (b) by reducing the tissue-mass density and thereby increasing spacer length. Only in case (b), spacer length can be considered as an independent part of the foraging behavior of the plant, whereas in our study spacer length is mainly an effect of biomass allocation into rhizomes. Such foraging sensu latu can easily be overseen when biomass is ignored. We, therefore, emphasize that studies which investigate the foraging capacity of clonal plants need to include measurements of spacer length, biomass and biomass allocation. In case of the fertilization experiment, foraging was more obvious, because due to comparable biomass, mean spacer length tended to be shorter and biomass allocation into rhizomes was lower in the fertilized plants than in the controls.

Overall, plants must function as a balanced system in terms of resource uptake and use, and resources may not be allocated independently from each other (e.g. Hirose, 1986; Ågren and Ingestad, 1987). On the assumption of different nutrient regimes at the two sites, the mechanisms for biomass allocation may be interpreted in the light of stochiometric theory. Under nutrient limitation, increased photosynthesis as a consequence of higher biomass can 
not increase biomass production because of missing nutrients. Consequently, it would be better for the plant to invest into: (a) roots to capture more nutrients; and (b) rhizomes in order to grow faster out of a limiting site. Only if a high nutrient uptake rate makes $\mathrm{C}$ the limiting factor, it is beneficial for the plant to produce aboveground photosynthetic tissue instead of below-ground biomass. At our study site, the allocation response of $P$. perfoliatus to sediment nutrient limitation allows for a patch expansion of roughly two-thirds of that under thriving conditions, although the biomass is only one-tenth. However, these patches have much shorter shoots and are less dense due to the: (a) lower number of plants per area; (b) lower number of ramets per plant; and (c) specific clonal architecture of the species (marginally longer spacers and less branchings). Hence, our study shows how plasticity of clonal architecture in $P$. perfoliatus may result in two patch types that constitute two distinctively different habitats within the littoral biocoenosis.

\section{Acknowledgements}

We gratefully acknowledge financial support by SFB454 Bodenseelitoral and RIZA/ Lelystad. Many thanks also to the research divers T. Jankowski, M. Mainberger, M. Mörtl, A. Müller, K. Pohlmann, O. Walenciak, and M. Wolf for their untiring work; to C. Gebauer and P. Merkel for chemical analyses and to H. Coops, M. Scheffer, M. Van den Berg and two anonymous reviewers for valuable comments on the manuscript.

\section{References}

Ågren, G.I., Ingestad, T., 1987. Root:shoot ratio as a balance between nitrogen productivity and photosynthesis. Plant Cell Environ. 10, 579-586.

Barko, J.W., James, W.F., 1997. Effects of submerged aquatic macrophytes on nutrient dynamics, sedimentation, and resuspension. In: Jeppesen, E., Søndergaard, M., Christoffersen, K. (Eds.), The Structuring Role of Submerged Macrophytes in Lakes. Springer, New York, pp. 197-214.

Bell, A.D., 1984. Dynamic morphology: a contribution to plant population ecology. In: Dirzo, R., Sarukhan, J. (Eds.), Perspectives on Plant Population Ecology. Sinauer Associates, Sunderland, MA, pp. 48-65.

Callaghan, T.V., Svensson, B.M., Bowman, H., Lindley, D.K., Carlsson, B.Å., 1990. Models of clonal plant growth based on population of dynamics and architecture. Oikos 57, 257-269.

Clevering, O.A., Hundscheid, M.P.J., 1998. Plastic and non-plastic variation in growth of newly established clones of Scirpus, Bolboschoenus maritimus L. grown at different water depths. Aquat. Bot. 62, 1-17.

De Kroon, H., Hutchings, M.J., 1995. Morphological plasticity in clonal plants: the foraging concept reconsidered. J. Ecol. 83, 143-152.

Downing, J.A., Rath, L.C., 1988. Spatial patchiness in the lacustrine sedimentary environment. Limnol. Oceanogr. 33, 447-458.

Evans, J.P., 1988. Nitrogen translocation in a clonal dune perennial Hydrocotyle bonariensis. Oecologia 77, 64-68.

Gafny, S., Gasith, A., 1991. Spatially and temporally sporadic appearance of macrophytes in the littoral zone of Lake Kinneret, Israel, taking advantage of a window of opportunity. Aquat. Bot. 62, 249-267.

Gedroc, J.J., McConnaughay, K.D.M., Coleman, J.S., 1996. Plasticity in root/shoot partitioning: optimal, ontogenetic, or both? Funct. Ecol. 10, 44-50.

Gerloff, G.C., Krombholz, P.H., 1966. Tissue analysis as a measure of nutrient availability for the growth of angiosperm aquatic plants. Limnol. Oceanogr. 11, 529-537.

Hilbert, D.W., 1990. Optimization of plant root:shoot ratios and internal nitrogen concentration. Ann. Bot. 66, 91-99. 
Hirose, T., 1986. Nitrogen uptake and plant growth. II. An empirical model of vegetative growth and partitioning. Ann. Bot. 58, 487-496.

Huber, H., Lukács, S., Watson, M.A., 1999. Spatial structure of stoloniferous herbs: an interplay between structural blue-print, ontogeny and phenotypic plasticity. Plant Ecol. 141, 107-115.

Hutchings, M.J., 1997. Resource allocation patterns in clonal herbs and their consequences for growth. In: Bazzaz, F.A., Grace J. (Eds.), Plant Resource Allocation. Academic Press, San Diego, pp. 161-189.

Hutchings, M.J., De Kroon, H., 1994. Foraging in plants: the role of morphological plasticity in resource acquisition. Adv. Ecol. Res. 25, 159-238.

Idestam-Almquist, J., Kautsky, L., 1995. Plastic responses in morphology of Potamogeton pectinatus L. to sediment and above-sediment conditions at two sites in the northern Baltic proper. Aquat. Bot. 52, 205-216.

Jeppesen, E., Søndergaard, M., Christoffersen, K., 1997. The structuring role of submerged macrophytes in lakes. Ecological Studies, vol. 131. Springer, New York.

Kautsky, L., 1991. In situ experiments on interrelationships between six brackish macrophyte species. Aquat. Bot. 39, 159-172.

Klimes, L., 2000. Phragmites australis at an extreme altitude: rhizome architecture and its modelling. Fol. Geobot. Phytotaxon. 35, 403-417.

Langeland, K.A., Sutton, D.L., Canfield Jr., D.E., 1983. Growth response of Hydrilla to extractable nutrients in prepared substrates. J. Freshwater Ecol. 2, 263-272.

Lauridsen, T.L., Pedersen, L.J., Jeppesen, E., Søndergaard, M., 1996. The importance of macrophyte bed size for cladoceran composition and horizontal migration in a shallow lake. J. Plankton Res. 18, 2283-2294.

Lehmann, A., 1997. Apports des systèmes d'information géographique à l'étude des plantes aquatiques submergées en milieu lacustre. Ph.D. Thesis, University of Geneva, Geneva.

Marbà, N., Duarte, C.M., 1998. Rhizome elongation and seagrass clonal growth. Mar. Ecol. Prog. Ser. 174, 269-280.

Molenaar, H., Barthélémy, D., De Reffye, P., Meinesz, A., Mialet, I., 2000. Modelling architecture and growth patterns of Posidonia oceanica. Aquat. Bot. 66, 85-99.

Müller, I., Schmid, B., Weiner, J., 2000. The effect of nutrient availability on biomass allocation patterns in 27 species of herbaceous plants. Perspect. Plant Ecol. Evol. Syst. 3, 115-127.

Pérez, M., Duarte, C.M., Romero, J., Sand-Jensen, K., Alcoverro, T., 1994. Growth plasticity in Cymodocea nodosa stands: the importance of nutrient supply. Aquat. Bot. 47, 249-264.

Reusch, T.B.H., Chapman, A.R.O., Groeger, J.P., 1994. Blue mussels, Mytilus edulis do not interfere with eelgrass, Zostera marina but fertilize shoot growth through biodeposition. Mar. Ecol. Prog. Ser. 108, 265-282.

Scheffer, M., De Redelijkheid, M.R., Noppert, F., 1992. Distribution and dynamics of submerged vegetation in a chain of shallow eutrophic lakes. Aquat. Bot. 42, 199-216.

Schmieder, K., 1997. Littoral zone-GIS of Lake Constance: a useful tool in lake monitoring and autoecological studies with submersed macrophytes. Aquat. Bot. 58, 333-346.

Stoll, P., Egli, P., Schmid, B., 1998. Plant foraging and rhizome growth patterns of Solidago altissima in response to mowing and fertilizer application. J. Ecol. 86, 341-354.

Terrados, J., Duarte, C.M., Kenworthy, W.J., 1997. Experimental evidence for apical dominance in the seagrass Cymodocea nodosa. Mar. Ecol. Prog. Ser. 148, 263-268.

Walser, R., 1996. Zur Rolle der Makrophytenbestände im Bereich von Flußmündungen am Bodensee-Obersee. Ph.D. Thesis, Universität Hohenheim, Germany.

Wessels, M., 1998. Geological history of the Lake Constance area. Arch. Hydrobiol. Spec. Iss. Adv. Limnol. 53, $1-12$. 